\title{
Characterization of Quaternary Deposits in the Bou Ahmed Coastal Plain (Chefchaouen, Morocco): Contribution of Electrical Prospecting
}

\author{
Yassyr Draoui ${ }^{1}$, Fouad Lahlou ${ }^{2}$ \\ Laboratory of Energy Engineering \\ and Materials, Faculty of Sciences \\ Ibn Tofail University \\ Kenitra, Morocco
}

\author{
Imane Al Mazini ${ }^{3}$, Jamal Chao ${ }^{4}$ \\ Laboratory of Natural Resources \\ Geosciences (NaResGeo) Faculty of \\ Sciences, Ibn Tofaïl University \\ Kenitra, Morocco
}

\author{
Mohamed Jalal El Hamidi ${ }^{5}$ \\ Regional Water Centre of Maghreb \\ LAMERN, Mohammadia School of \\ Engineers, Mohammed V University \\ Rabat, Morocco
}

\begin{abstract}
The Bou Ahmed plain, which is part of the internal area of the Rif, is located along the Mediterranean coast, 30 kilometers of Oued Laou town. This basin is made up by a quaternary filling mainly formed by detrital fluvial facies, channeled conglomerates surmounted by fluvial sand interlayered with pebbles; these facies can be new potential aquifers formations areas. Therefore, the main goal of this study is to build a lithostratigraphic three dimensional model to identify the hydrogeological units and the reservoir geometry of the Bou Ahmed plain. In order to achieve this goal, we have created a database made up by Vertical Electrical Sounding surveys and drilling data integrated into a Geographic Information System. This database allowed us to establish a three-dimensional model of the bottom, geoelectric cross-sections, isopach and isoresistivity maps of new potential aquifers units. This approach allowed us to explain the modalities of deposition for the quaternary deposits of the Bou Ahmed plain and to identify potential hydrogeological reservoirs. These results will also be used to develop a hydrodynamic model based on MODFLOW code in the Bou Ahmed aquifer.
\end{abstract}

Keywords-Bou Ahmed plain; hydrogeological units; reservoir geometry; vertical electrical sounding surveys; geographic information system; quaternary deposits

\section{INTRODUCTION}

Covering an area of approximately $12 \mathrm{~km}^{2}$, the Bou Ahmed plain is located in northern Morocco between the latitudes $35^{\circ} 15^{\prime}-35^{\circ} 25^{\prime} \mathrm{N}$ and the longitude $5^{\circ} 00-4^{\circ} 55^{\prime} \mathrm{W}$, and is part of Chefchaouen province (Fig. 1). This plain is materialized by a Plio-Quaternary infill containing new potential aquifers formations. The plain is among the coastal alluvial plains in Morocco, which are highly coveted because of the high population densities and agricultural activities, which can cause overexploitation and/or degradation of the groundwater quality. This situation causes significant drops of the groundwater level and consequently concern the decision makers responsible for the management and planning of water resources.

As a result, the groundwater of Bou Ahmed aquifer was the subject of numerous geological, hydrogeological studies, and reconnaissance geophysical survey [1],[2],[3]. Despite these explorations, the mastery of the bottom geometry and the deposits that they surmount limit certain interpretations of the phenomena determined for the management of water resources in the region.

The objective of this work aims to specify the structure of the Pliocene bottom, and to identify new potential aquifers intervals, with a view to reasonable management of these hydrogeological reservoirs. To achieve this objective, we used all data collection (geoelectric cross-sections data, hydrogeological drilling data and conductivity analysis data) were processed and led to: (i) Study the lithostratigraphy characteristics of the Bou Ahmed aquifer; (ii) Build a threedimensional lithostratigraphic model from boreholes data and Vertical Electrical Sounding (VES) surveys data of the Bou Ahmed aquifer; (iii) The production of new potential aquifers levels in terms of thickness and resistivity; (iv) To compare between the conductivity map and the isoresistivity map was performed.

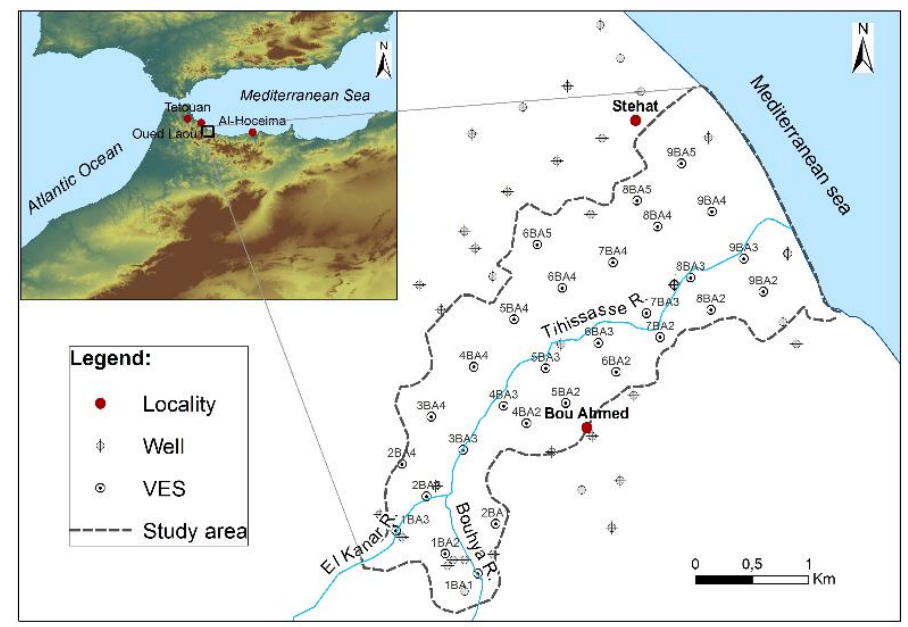

Fig. 1. Geographic Location Map of the Bou Ahmed Aquifer Including the Collected and used Database (Wells/Drilling/VES).

\section{Geological SETting}

The Bou Ahmed plain is a geological entity of the internal Rif [4], which is a domain made up by three structural groups piled one on top of the other (Fig. 2): the "Sebtides", the "Ghomarides", and the "Calcareous Dorsale" [5]. The 
Paleozoic and limestone units form, during the sedimentation of the Rif domain, a shallow in the middle and axial position relative to the "internal" domain ("ultra flyschs" origin) and to the "external" domain [6].

The Bou Ahmed plain is a coastal graben (paleo-golf) which resulted from the Pre-Pliocene subsidence of the Mediterranean basin which was later invaded by the Pliocene Sea ([7], [8] in [3]). This basin has long been considered as a lower Pliocene ria established in ancient Messinian canyons [9], [10].

From the lithostratigraphic standpoint, the study area is in the form of a depression filled from bottom to top with (Fig. 3):

- Palaeozoic basement: the base of the Bou Ahmed basin is materialized by crystallophyllian ("Gneiss" and "Mica-schist") and "peridotite" terrains of the Beni Bousra unit [12]. These formations correspond to the lower "sebtides" which constitute the deepest units of the internal Rif [3].

- Pliocene: in the lower Pliocene the Mediterranean coastal depressions may tend to subside. This allowed the entrance of the Sea and the establishment of a thick marl formation of Pliocene age [3]. This formation is surmounted by coarse conglomerate facies which have become more abundant in the valley of the Tihissasse River [10].

- Quaternary: the basin is covered by quaternary formations formed essentially by purely fluvial detrital facies (channeled conglomerates surmounted by fluvial sand interlayered with pebbles). These more or less coarse detrital formations are poorly classified in the Tihissasse River. At the upstream valley, develops coarse detrital deposits (pebbles and gravels of a schist nature, sandstone, and slightly calcareous). However, towards the downstream medium-grained sandy deposits predominate [2]. This architecture is due to the dynamics of the Tihissasse River from upstream to downstream.

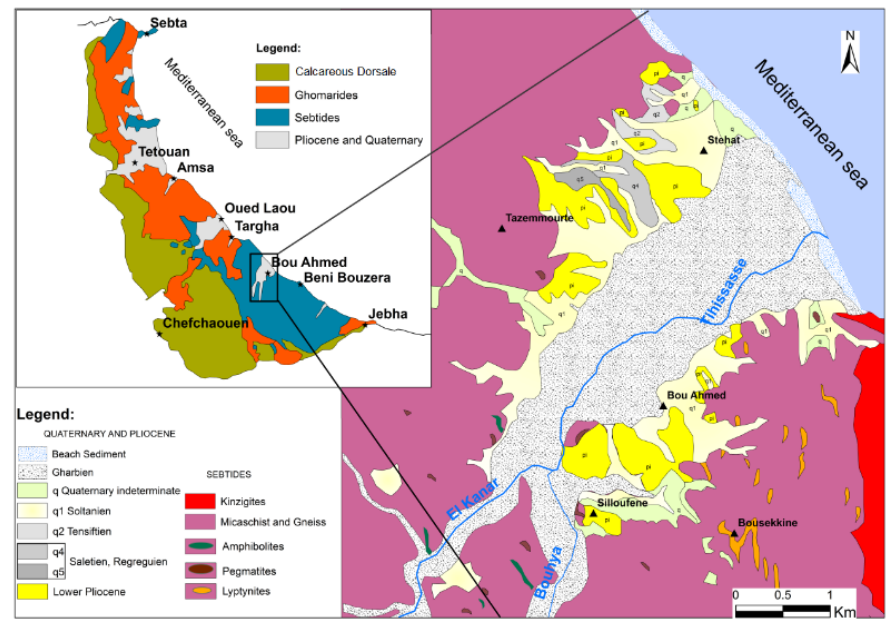

Fig. 2. Location Map of the Bou Ahmed Area in the Internal Rif (Map Simplified from [11]).

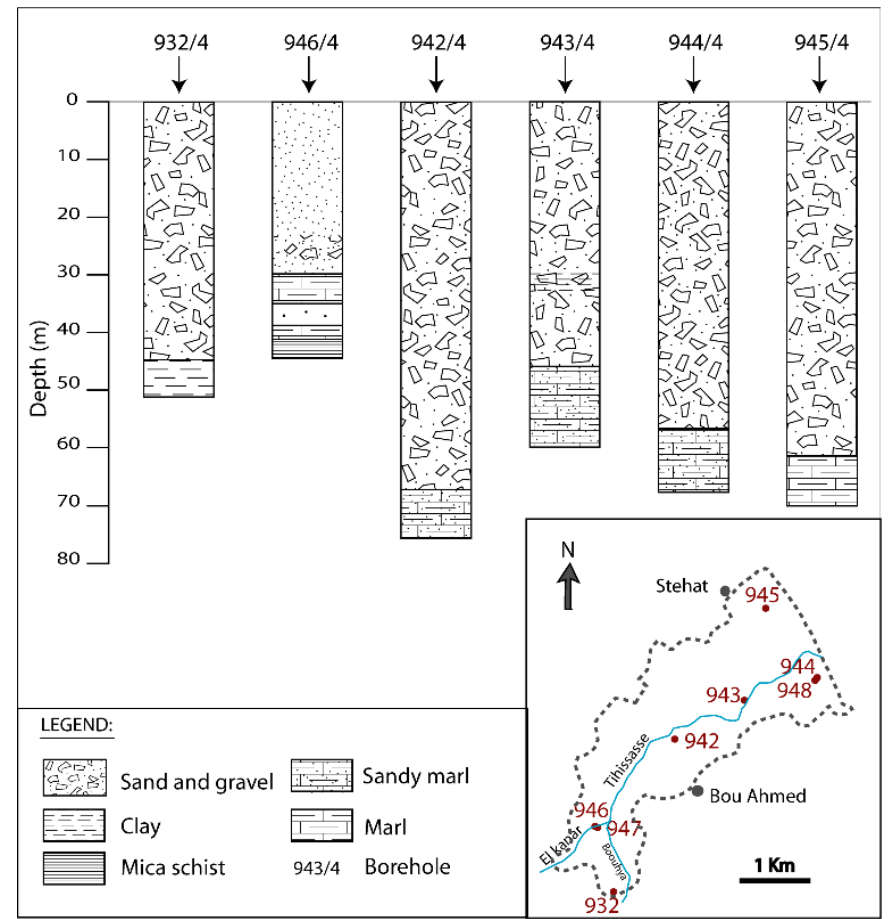

Fig. 3. Synthetic Litho-Stratigraphic Columns in the Study Area.

\section{METHODOLOGY}

The database used in this work includes hydrogeological and geoelectric drilling data (Fig. 1) hence we used 16 hydrogeological boreholes, six of which reach the lower Pliocene marly bottom.

The electrical data includes six geoelectric cross-sections processed, resulting from the interpretation of 29 VES surveys [1]. The geoelectric method, using electrical survey technique, is one of the first methods used in electrical prospecting in continuous current [13], whose usefulness in the establishment of shallow structures is currently well established [14]. The method is used to characterize the geological formations crossed (thickness and lithological nature) vertical to the measurement point [15] and thus to highlight the stratigraphic evolution of the studied deposits during a lateral correlation [16], [17]. This method is based on the principle of Ohm's law: the injection into the ground of a continuous current at a very low frequency, therefore, the measurement of the voltage allows to reveal the true resistivity of the formations crossed using the Schlumberger array (Fig. 4). In practice, in the field, it uses two steel electrodes for current injection $\mathrm{A}$ and $\mathrm{B}$ (or $\mathrm{C} 1$ and $\mathrm{C} 2$ ), as well as two copper electrodes for the measurement of the potential $\mathrm{M}$ and $\mathrm{N}$ (or P1 and P2) between which the potential difference $\Delta \mathrm{V}$ is due to the injection of current by $\mathrm{A}$ and $\mathrm{B}$. 


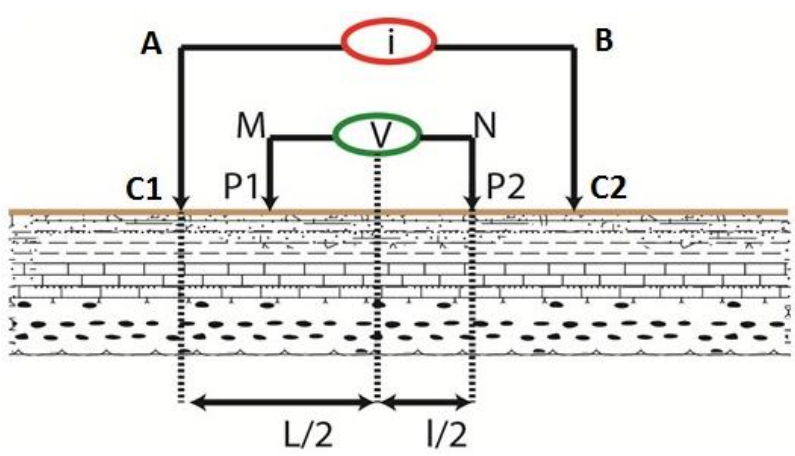

Fig. 4. Electrodes Location for the Schlumberger Array [18].

The three-dimensional representation allows a better understanding of the spatial distribution of the geological structures of the ground. It serves as the basis for a wide range of scientific activities, notably in the area of natural resources assessment and environmental engineering [19], [20], [21]. The three-dimensional (3D) geological modelling is a technology still in development for geological studies used for the exploration of mineral resources, for the quantitative estimation of mineral resources and petroleum exploration [20]. This approach allows 3D modelling of complex and irregular geological objects using geological maps, survey records, geological, geophysical, and data information, etc. [22]. All of this data was integrated into a geographic information system in order to build a 3D geoelectric model and geoelectric correlation sections in different directions.

Knowing that electrical and mechanical surveys are punctual character, and in order to illustrate the characteristics of the various electrical levels, a spatial interpolation method has been used in this work. The Inverse Distance Weighting (IDW) method makes it possible to determine the value of a "node" from a limited number of sampling points [23] in calculating the average values of its points in the vicinity of each processing cell. It is a powerful geostatistical method because it takes into account the spatial variability of the parameters [19], [24]. Currently operating software that is used to model the surface and the sub-surface, includes several spatial interpolation algorithms such as inverse distance weighting, kriging, etc. [25].

Highlighting the relationship between the precision of the Digital Elevation Model (DEM) and interpolation techniques has been the subject of many researches, namely for the creation of a 3D model [19], [20], [23], [26] or for the implementation of the precision of interpolation techniques [24], [27], [28]. The interpolation method thus recommended in the modelling of the sub-surface is the IDW, which, in the estimation of the unknown points, gives more weight to the closest known points instead of the distant ones. The IDW method is very polyvalent, easily programmable, and understandable. In addition, it gives very precise results in data with a wide range of interpretations [28].

\section{RESULTS AND DISCUSSION}

\section{A. Bottom Geometry}

The three-dimensional model of the blue marl bottom (roof of the lower Pliocene) of the Bou Ahmed basin (Fig. 5) is established by combining geoelectric data and hydrogeological drilling. The geometry illustrated by this model is mainly characterized by the presence of a large bowl in the NE-SW direction open on the Mediterranean Sea (Fig. 5). This structure is bordered by high areas and affected by a residual relief in the central part of the study area; the growth of this wrinkle seems to be responsible for the separation of two depressions: the first located to the southwest of the basin at the base of the confluence of the El Kanar and Bouhya rivers (depth of about $30 \mathrm{~m}$ ), and the second located to the northeast of the study area with a depth which increases by about $70 \mathrm{~m}$ towards the sea.

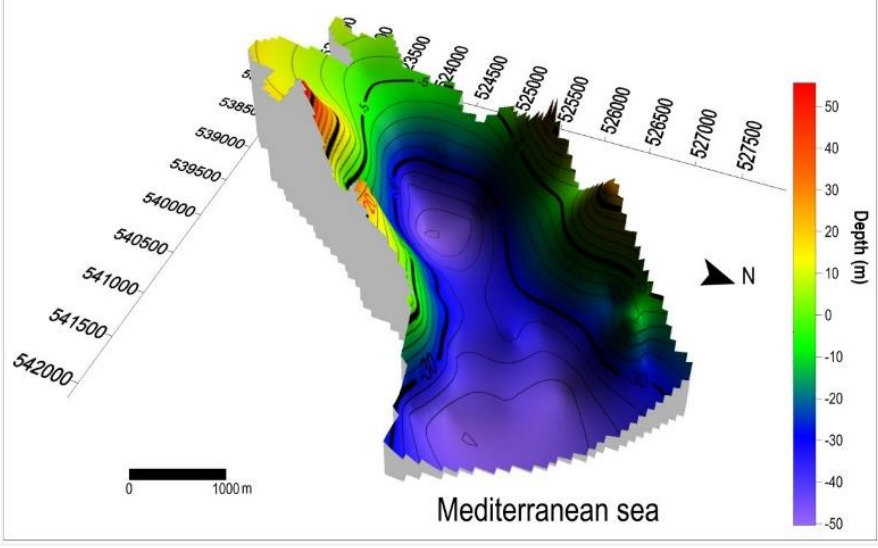

Fig. 5. Three-Dimensional Model of the Blue Marl Bottom (Roof of the Lower Pliocene).

\section{B. Geoelectric Characterization of Quaternary Deposits}

The establishment and evolution of the Plio-Quaternary deposits of the Bou Ahmed plain is characterized by the description of the geometry configuration, and the variation of the resistivity values of the geoelectric intervals defined using the geoelectric cross-sections from different directions (Fig. 6 and 7). The geoelectric cross-sections carried out in directions N-S, NE-SW and E-W (Fig. 6 and 7) show that the filling of the quaternary age in the study area is organized into several geoelectric levels: Rs, Cs, R2, C1, R1, and the upper levels (Fig. 6 and 7).

The isometric view, established through two perpendicular sections, highlighted five important geoelectric intervals (Fig. 6). The basal part of the basin is constituted by a geoelectric horizon Rs, which corresponds, according to the boreholes, to mica-schists forming part of the Paleozoic basement.

This horizon is surmounted by the geoelectric conducting interval Cs (limiting an average resistivity interval of $25 \Omega . \mathrm{m}$ (Fig. 6 and 7). According to the drilling wells, this horizon coincides with the blue marl bottom of the lower Pliocene (Fig.7). The geometry of its roof is illustrated by the threedimensional model in Fig. 5, the roof shape of this interval on the cross-sections (Fig. 6 and 7) confirms the geometry in high and low areas. The geometrical configuration of the roof of this geoelectric interval confirms the structuring in high and low zones described in the three-dimensional model of Fig. 5. This interval is surmounted by the relatively resistant geoelectric interval R2 which expressed by resistivity values ranging from 
123 to $340 \Omega$.m. Its correlation to mechanical drilling shows that it consists of coarse detrital formations (coarse sands and gravels) with clayey passages (Fig. 7). This interval is covered by a relatively conductive $\mathrm{C} 1$ geoelectric interval (the average resistivity is $35 \Omega . m$ consisting essentially by sedimentation.
The relatively resistant geoelectric interval R1 (123 to 278 $\Omega . \mathrm{m})$, its correlation to mechanical drilling shows that it consists of coarse detrital formations (coarse sands and gravels) (Fig. 7).

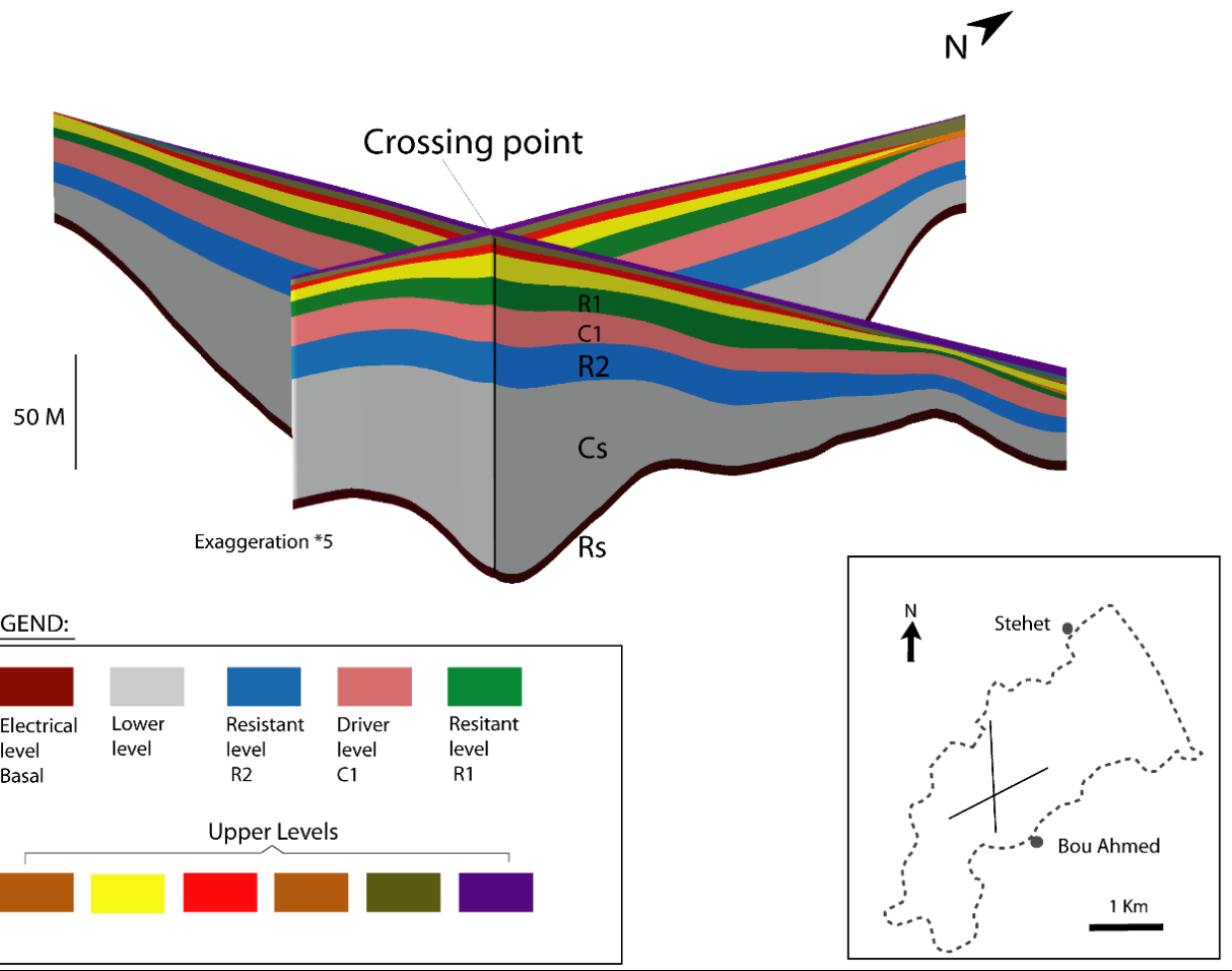

Fig. 6. Fence Diagram Sections (N-S and NE-SW Direction) in the Study Area.

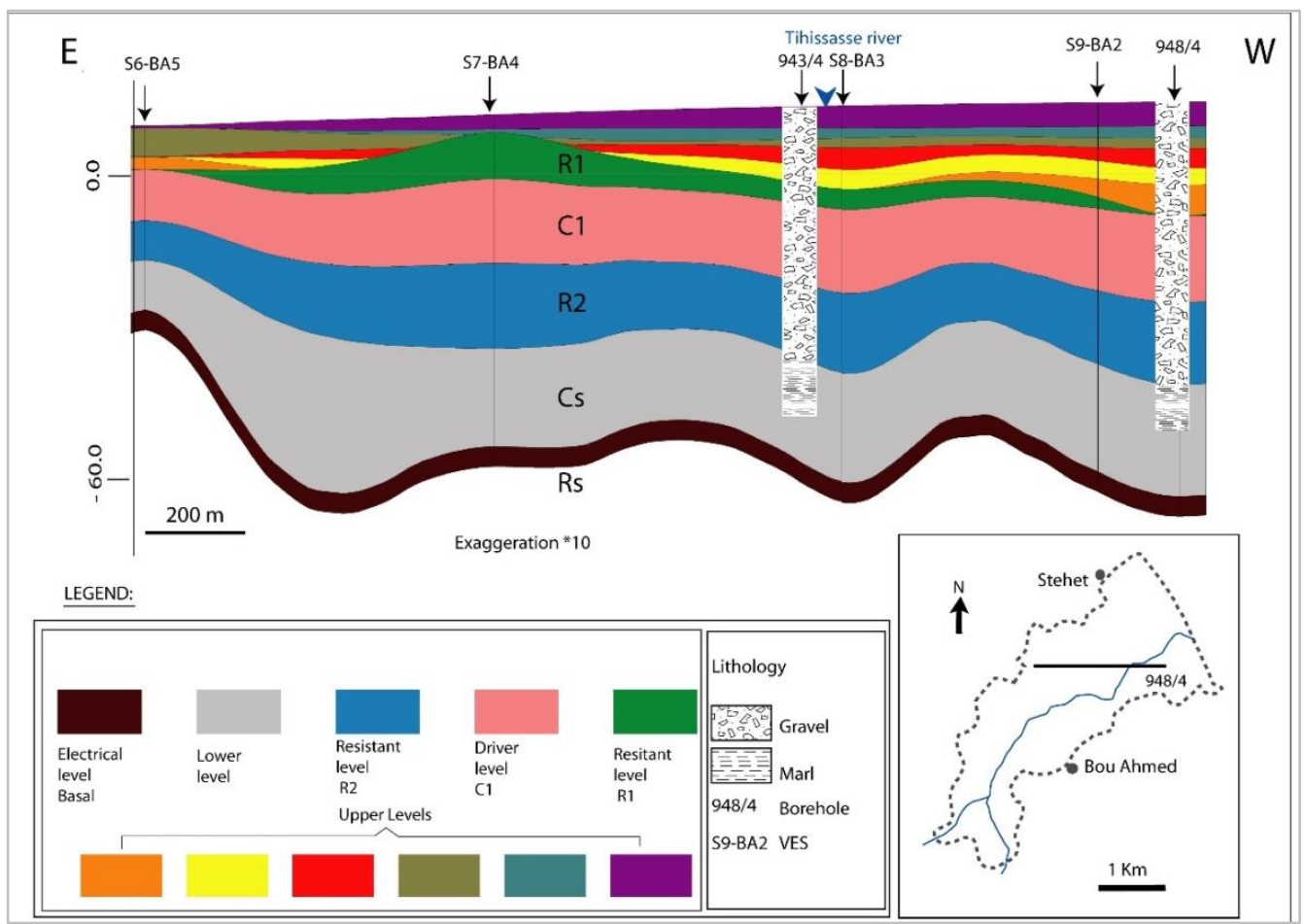

Fig. 7. E-W Direction of Geoelectric Cross-Section in the Centre of the Study Area. 
The geoelectric levels end with the alternation of the resistant and conductive levels (Upper levels) of a limited extension (Fig. 6 and 7).

It should be noted that on the scale of the Bou Ahmed plain the filling generally is on a marly bottom. The filling is, sometimes to the west and Northwest of the basin, directly formed on the Paleozoic where the bottom corresponds to mica-schists.

\section{Potentially Aquifer Intervals ( $R 2$ and $R 1$ )}

The geoelectric intervals described above, show that the most important levels, in terms of thickness and resistivity, are the R2 and R1 (Fig. 8 and 9) which can be considered as new potential aquifers levels. The spatial distribution of these geoelectric levels is characterized by using maps of isopach and isoresistivity for each geoelectric interval (Fig. 8 and 9).

1) The geoelectric interval R2: The isopach map of the geoelectric interval R2 shows that the largest thicknesses are organized in the form of a NE-SW oriented band (Fig. 8-A). The location of this band in relation to the Tihissasse River shows that the latter has migrated to the Southeast. The comparison between the isopach map of the geoelectric interval R2 (Fig. 8-A) and the roof of the bottom map (Fig. 5) shows that the large bowl is located almost in the same depressions detected on the roof of the Pliocene bottom (Cs). This shows that these bowls function, during the phase of setting up this interval, as sediment traps.

From an electrical standpoint, the spatial distribution of the resistivity values of the geoelectric interval R2 (Fig. 8-B) shows that the zones with high resistivity (340 $\Omega$.m) are located mainly in the East and in the Southwest of the study area (Fig. 8-B). The calibration of these zones to the boreholes shows that this interval consists of coarse sands and gravels. This reflects the fluvio-estuarian environment linked to the paleo-Tihissasse, which dominated in plio-quaternary study area. In the Northwest of the Bou Ahmed town, a decrease in resistivity values is to be observed which goes towards the center of the study area (Fig. 8-B) where the marly bottom is rising (Fig. 5).

2) The geoelectric interval R1: The spatial distribution of thickness of the geoelectric interval R1 shows a depression in the center of the plain (14 m) (Fig. 9-A). The comparison of this map with the isopach map of the interval R2 shows that the depression opening on the Mediterranean Sea identified on the geoelectric interval R2 has undergone filling, hence the depression located in the center of the study area continued to play its role as a sediment trap. The placement of this depression, related to the bottom geometry (Fig. 5), shows that there is a continuous subsidence during the quaternary.

The lateral variation of the resistivity values of this interval shows that the zones with high resistivity are very small in the central part of the study area (Fig. 9-B). This can be linked to the clay nature of the layers or to the degradation of the chemical quality of the water.
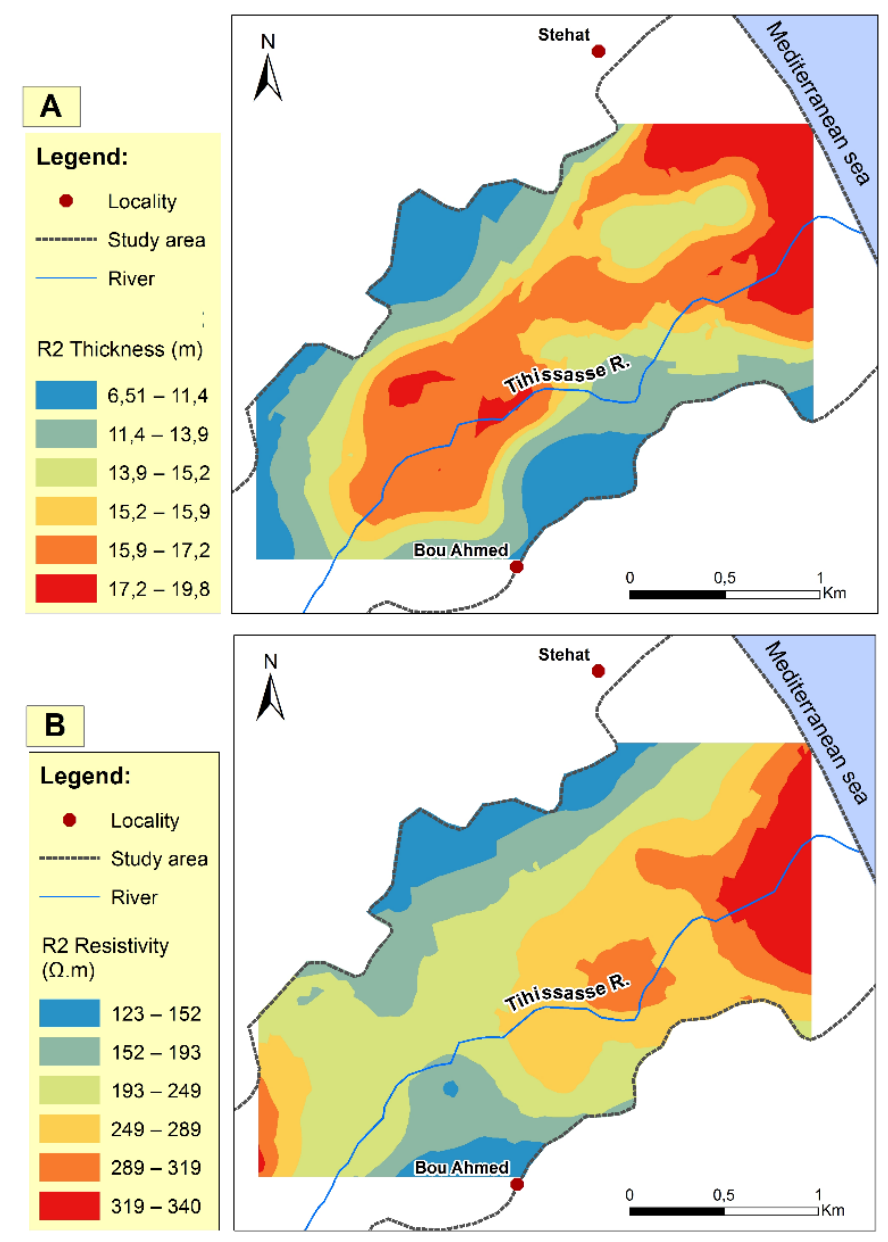

Fig. 8. Maps of the Resistant Level R2 (A- Isopach Map and BIsoresistivity Map).

In order to complete the interpretation of the electrical results, we carried out a measurement of the electrical conductivity of the groundwater wells in the study area. Electrical conductivity is the inverse of electrical resistivity, it translates the capacity of an aqueous solution to conduct electric current and the degree of global mineralization, and thus it provides information on the salinity rate.

Spatial distribution of the conductivity measured on the various groundwater wells of the Bou Ahmed plain shows that the values are included in the range $[0.5 \mu \mathrm{s} / \mathrm{cm} ; 4.3 \mu \mathrm{s} / \mathrm{cm}]$ (Fig. 10). The conductivity field highlights a spatial variability of this parameter passing from the edges to the central part of the study area (Fig. 9). The most conductive areas $(>1.46$ $\mu \mathrm{s} / \mathrm{cm})$ are located on the eastern and western margins of the plain (Fig. 9). Analysis of the lithological data in these areas reveals that the character of the high conductivity values is related to the flow of groundwater in contact with the bottom, sometimes materialized by marls and sometimes by micaschist. According to [29], this increase in conductivity can be interpreted as a consequence of the longer contact time with marly sandstones, which has allowed the development of ion exchange processes. 

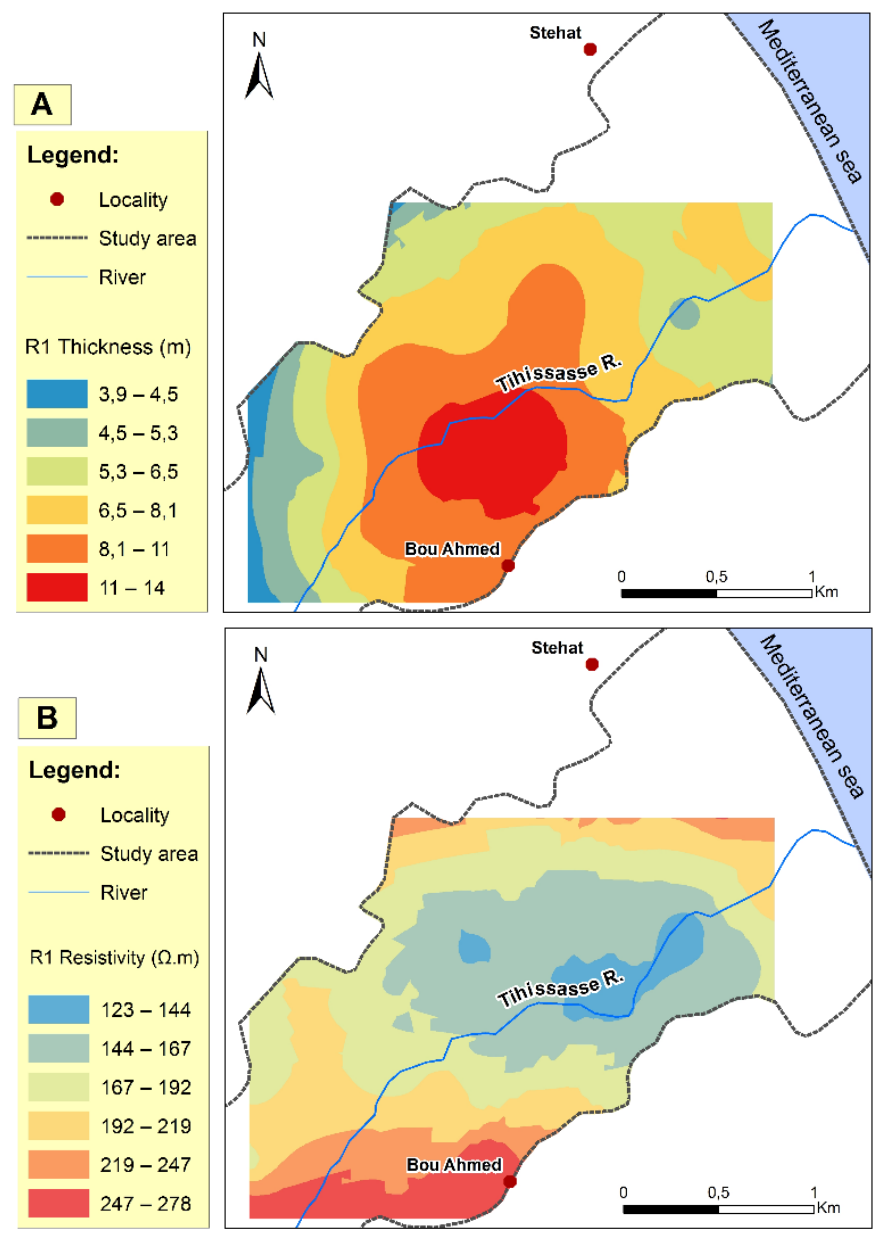

Fig. 9. Maps of the Resistant Level R1 (A- Isopach Map and B Isoresistivity Map).

Low conductivity values $(<0.95 \mu \mathrm{s} / \mathrm{cm})$ are recorded in the center of the study area. This decrease is related to the surface waters of the rivers supplying the aquifer; El Kanar and Bouhya Rivers. The latter cross terrain characterized respectively by shale formations, carbonate rocks and "Calcareous Dorsale".

The comparison between the conductivity map (Fig. 10) and the isoresistivity of the geoelectric interval R2 map (Fig. 8B) shows a reciprocal proportionality between the values whose highest values of conductivity coincide with the low one's resistivity values (Fig. 10).

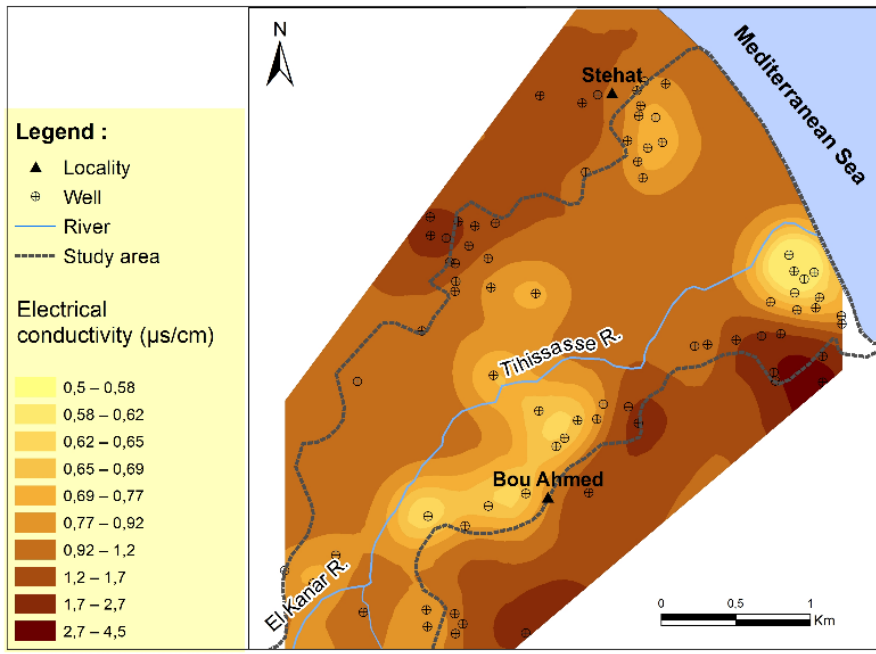

Fig. 10. Distribution Map of the Electrical Conductivity $(\mu \mathrm{s} / \mathrm{cm})$ in the Study Area.

\section{CONCLUSION}

Computer technology and 3D modelling of the subsurface are being increasingly used in different fields of geo-resources. The subsurface data obtained at regular spaces play an important role in the detection of structures of the ground.

At the level of the Bou Ahmed aquifer, the method applied was able to show the complexity of the aquifer. Indeed, it was composed by several levels of different nature and age. The 3D model, the correlation of cross-sections, the fence diagram sections, and the level distribution maps produced clearly show the geometry of the different resistant levels potentially aquiferous in the Bou Ahmed aquifer.

Geophysical reconnaissance by VES of the water table made it possible to show the presence of a depression centered in the Bou Ahmed aquifer. This anomaly corresponds to the confluence zone of the main rivers of the plain (El kanar and Bouhya Rivers).

Tectonic structures were not taken into account in the development of the 3D model of the aquifer due to the lack of data and precision.

The results obtained in this study confirmed previous studies, and carried out new interpretations of the subsurface based on 3D modelling.

Besides, this study allowed us to integrate the 3D lithostratigraphic model of Bou Ahmed aquifer to the layered conceptual model, and prepare the input data such as hydraulic conductivity for groundwater flow model which will be a key decision support system for the decision makers in water resources management. 


\section{REFERENCES}

[1] D.G.H, Etude par prospection électrique, nappes d'Oulad Ogbane, Ksar Es-Sghir, Emsa et Azla (Province de Tétouan), nappe de Bou Ahmed et Targha (Province de Chefchaouene), Maroc. 2000.

[2] DRHL, Synthèse hydrogéologique de la plaine de Bou Ahmed, province de Chefchaouen, Maroc. 1994.

[3] A. El Attar, « Contribution à l'étude hydrogéologique et hydrochimique des aquifères côtiers d'Amsa et de Bou Ahmed (Maroc Nord Occidental) », 2012.

[4] J. Thauvin, « Ressources en eau du Maroc, domaine du Rif et du Maroc oriental », Notes Mém. Serv. Géologique Maroc, vol. 231, 1971.

[5] K. El Kadiri, K. El Kadiri, et A. Rahouti, « Sédimentologie et ichnologie des calciturbidites du Crétacé supérieur-Oligocène inférieur de la série Maurétanienne (nappe des Béni Ider, Rif septentrional, Maroc): implications paléogéographiques », Bull. L’Institut Sci. Rabat, vol. 25, p. 73-91, 2003.

[6] A. Amraoui, « Hydrogéologie de la dorsale calcaire du Rif (Maroc septentrional) », 1988.

[7] M. Benmakhlouf, « Genèse et évolution de l'accident de Tétouan et son rôle transformant au niveau du Rif septentrional (Maroc)(Depuis l'oligocène jusqu'à l'actuel) », 1990.

[8] R. Saji, «Evolution tectonique post Nappes dans le Rif septentrional (Maroc): ses effets sur l'ouverture de la mer d'Alboran », Third Cycle Thesis Univ. Mohammed V Rabat Moroc., 1993.

[9] J.-L. Morel, « Evolution récente de l'orogène rifain et de son avant-pays depuis la fin de la mise en place des nappes (Rif, Maroc) », 1987.

[10] J. Rampnoux, J. Angelier, B. Colletta, S. Fudral, M. Guillemin, et G. Pierre, "Sur l'évolution néotectonique du Maroc septentrional », Géologie Méditerranéenne, vol. 6, no 4, p. 439-464, 1979.

[11] G. Suter, Carte géologique de la chaîne rifaine 1: 500,000. Service géologique du Maroc, 1980.

[12] O. Saddiqi, I. Reuber, et A. Michard, « Sur la tectonique de dénudation du manteau infracontinental dans les Beni Bousera, Rif septentrional, Maroc », Comptes Rendus Académie Sci. Sér. 2 Mécanique Phys. Chim. Sci. Univers Sci. Terre, vol. 307, no 6, p. 657-662, 1988.

[13] S. Penz, « Modélisation et inversion de données électriques en courant continu: vers une prise en compte efficace de la topographie », 2012.

[14] J. Asfahani, Y. Radwan, et I. Layyous, « Integrated geophysical and morphotectonic survey of the impact of Ghab extensional tectonics on the Qastoon dam, Northwestern Syria », Pure Appl. Geophys., vol. 167, no 3, p. 323-338, 2010.

[15] W. M. Telford, W. Telford, L. Geldart, R. E. Sheriff, et R. Sheriff, Applied geophysics, vol. 1. Cambridge university press, 1990.
[16] I. Al Mazini, A. Mridekh, M. Kili, B. El Mansouri, M. El Bouhaddioui, et B. Magrane, «Plio-quaternary deposits in the Eastern Rharb (Nw Morocco): Electrosequential characterization », J. Afr. Earth Sci., vol. 138, p. 32-41, 2018.

[17] M. E. Bouhaddioui, A. Mridekh, M. Kili, B. E. Mansouri, E. H. E. Gasmi, et B. Magrane, «Electrical and well log study of the PlioQuaternary deposits of the southern part of the Rharb Basin, northern Morocco », J. Afr. Earth Sci., vol. 123, p. 110-122, 2016.

[18] H. Schlumberger, « Synovial gout in the parakeet. », Lab. Investig. J. Tech. Methods Pathol., vol. 8, p. 1304-1318, 1959.

[19] S. Akiska, İ. S. SAYILI, et G. DEMİRELA, " Three-dimensional subsurface modeling of mineralization: a case study from the Handeresi (Çanakkale, NW Turkey) Pb-Zn-Cu deposit », Turk. J. Earth Sci., vol. 22, no 4, p. 574-587, 2013.

[20] O. Kaufmann et T. Martin, « Reprint of "3D geological modelling from boreholes, cross-sections and geological maps, application over former natural gas storages in coal mines"[Comput. Geosci. 34 (2008) 278290] », Comput. Geosci., vol. 35, no 1, p. 70-82, 2009.

[21] S. Rziki, A. Alansari, E. Mouguina, J. Simard, M. Zouhair, et L. Maacha, «Apport du modèle géologique et géophysique 3D dans le développement du gisement polymétallique de Draa Sfar (Massif hercynien des Jebilet centrales, Maroc) », Estud. Geológicos, vol. 68, no 1, p. 29-40, 2012.

[22] A. Zanchi, S. Francesca, Z. Stefano, S. Simone, et G. Graziano, « 3D reconstruction of complex geological bodies: Examples from the Alps », Comput. Geosci., vol. 35, no 1, p. 49-69, 2009.

[23] G. Wang et L. Huang, « 3D geological modeling for mineral resource assessment of the Tongshan $\mathrm{Cu}$ deposit, Heilongjiang Province, China », Geosci. Front., vol. 3, no 4, p. 483-491, 2012.

[24] T. Q. Binh et N. T. Thuy, « Assessment of the influence of interpolation techniques on the accuracy of digital elevation model », VNU J. Sci. Earth Environ. Sci., vol. 24, no 4, 2008.

[25] J. Li et A. D. Heap, « A review of spatial interpolation methods for environmental scientists », 2008.

[26] A. A. Fazal et M. ATMSH, « 3-Dimensional Analysis and Reserve Estimation of Barapukuria Coal Basin, Dinajpur, Bangladesh », Int Res J Geo Min, vol. 4, no 7, p. 176-187, 2014.

[27] Y. Gratton, « Le krigeage: la méthode optimale d'interpolation spatiale », Artic. Inst. Anal. Géographique, vol. 1, 2002.

[28] N. S.-N. Lam, « Spatial interpolation methods: a review », Am. Cartogr., vol. 10, no 2, p. 129-150, 1983.

[29] A. El Attar, K. El Morabiti, L. Molina, F. Sánchez-Martos, Y. El Kharim, et others, «Consideraciones hidrogeoquímicas sobre el acuífero detrítico costero de Bou Ahmed (Marruecos) », Geogaceta, vol. 46, p. 159-162, 2009. 